\title{
Andrzej Leder, Prześniona Rewolucja. Ćwiczenia z logiki historycznej, Krytyka Polityczna, Warszawa 2014, pp. 205
}

$\mathbf{T}$ he history of the Polish nation is not simple. Over the years Poles struggled with the invasions of enemies, three partitions and uprisings which sometimes should not be mentioned due to the bloodshed. First our grandparents and then our parents experienced war which clearly afflicted the world in the $20^{\text {th }}$ century. The communist oppression was the next stage of the fight for survival, and then came the revolution. It was breaking away from the claws of the cold real socialism, winning freedom and democracy, which in 2015 , celebrated its $25^{\text {th }}$ anniversary. However, a question arises whether the revolution which took place at the turn of the 1980s and 1990s, was not preceded by another revolution? The revolution that was dreamed by Poles? Such a question Andrzej Leder raises in a book entitled: Prześniona Rewolucja. Ćwiczenia z logiki historycznej [Dreamed Revolution. Historical logic training], published by Krytyka Polityczna publishing house. Andrzej Leder is a professor at the Institute of Philosophy and Sociology of the Polish
Academy of Sciences. He is also known as the author of books: Przemiana mitów, czyli życie w epoce schyłku. Zbiór esejów (1997); Nieświadomość jako pustka (2001); Nauka Freuda w epoce Sein und Zeit. A. Leder is involved in the philosophy of culture and by Prześniona Rewolucja. Ćwiczenia z logiki historycznej, he tries to present to the reader what has shaped Poles and what has had an impact on the present attitude.

The main thesis of the book is that between 1939-1956 a social revolution took place on the Polish lands, in particular a bourgeois revolution, which "was made by the Others without the possibility for the most subjective parts of the nation to equate with decisions, actions and responsibility for what happened. As a result, the revolution was experienced by the Polish society as a dreadful dream". According to A. Leder, this revolution was exceptionally brutal and catastrophic. It clearly took over human consciousness, changing them completely. The unrealized revolution was one of those events that according to the 
author have changed the thinking of the Polish society and brought Poles closer to the citizens' awareness of the Western countries. The author draws attention to the fact that all Poles' needs that were connected with socio-structural changes had been carried out without their awareness and without them present, i.e. wiping the Jewish community and fall of the higher classes. According to the author, the foundations of the revolution at the turn of 1980s and 1990s, the birth of the Solidarity movement and creation of the middle class society was triggered by hatred and terror. The hate was directed mainly at all Jews and the terror was introduced by the Stalinist authorities.

The introduction of the reviewed book refers to the objective which the author set for himself, and which the reviewer mentioned above. A. Leder presents also the terminology which he later uses in the presentation of the dreamed revolution. He uses the terminology associated with psychoanalysis such as the field or fantasy that is presented in a clear, comprehensive way even for a layperson. In the text the reader can also see the concept of imagination, understood by Charles Taylor as something that would allow social practices by giving them a peculiar sense. Therefore, the first advantage of reading this book is the fact that first the readers can familiarize themselves with the concepts, then try to immerse in their meaning and importance, and finally together with the author can juxtapose them with a particular situation, which took place in recent history. Then, A. Leder presents the main thesis that was already mentioned at the beginning by the reviewer.

In the next section the author focuses on the Holocaust, which according to A. Leder was one of the key parts of the revolution. The Holocaust seems to be an undoubtedly inconvenient and difficult subject for Poles. A. Leder shows the relationship that prevailed between the Jews and Poles as cold. The author's claims concerning the relations are followed by quotes and reminiscences of those times. The author of Dreamed Revolution mentions the situation that the properties of Jews were taken over by Poles. He also indicates the absence of empathy toward the Jewish community during the German occupation.

Undoubtedly, the author touches upon extremely important parts of the history of the Polish nation, the shaping of the values in the society. However, the reviewer would like to point out that this part of the work lacks of balance. Moreover, it is worth mentioning that there were many historical events which contradict the above claims. In this period present were associations that dealt with granting aid to members of the Jewish community, which suggests that the author's argument about the lack of empathy may not be entirely valid.

However, the reviewer agrees with the book summary which the author presented at the end of this part. In particular, it points to the factors connected with citizens' unconscious and denying sense of guilt with regard to the situation of the Jewish community in the years 1939-1945 . It formed some values of the Polish society and a significant lack of trust between themselves, due to the fact that historical experiences have taught Poles to assess the situation in an unequivocal way, without the possibility of analysis.

The next part A. Leder devotes to agricultural reform also called by him the industrial terror. It depicts the reform which took place in the Polish lands and 
presenting this the author has in mind the change of Poles mentality together with the system change. In the society the ideal nobleman was changed to the ideal party official member. A. Leder relates directly to the extermination of noble imagination by the gentry imagination of the communist government. The gentry were exterminated just like the elite that were deeply rooted in the Polish society and primarily peasants had benefited from this. As A. Leder points out, the destruction of gentry did not in any way cause a creation of a new symbolic field in its place. The communist authorities in Poland, despite extensive authority, failed to convince the public enough to create something new. The elimination of the elite lasted just as the destruction of the Jews since 1939 and according to A. Leder had an impact on the development of the Polish society.

In the last part the author attempts to address the dreamed revolution that took place during the period 1939-1956 by the prospect of the next thirty three years of Polish People's Republic. The author indicates the situation where the revolution made by foreign hands, made the Polish society incapable of being subjective again. Undoubtedly, he also indicates an important issue that if the society does not critically review this revolution, which took place in a dream, it will not be able to reach its roots, create own values, and consequently it will be unable to find its real social identity.

Prześniona Rewolucja. Ćwiczenia z logiki historycznej consists of several parts. It starts with a few pages of introduction.
The first part pertains to the revolution. In the next part the author refers to the Holocaust and in subsequent parts to the reform of agricultural policy and the industrial terror as the author named it. The layout of Leder's book is consistent. It contains logical arguments and prompts reader to think. As the reviewer mentioned before, the book lacks a reference to the previously mentioned aid for the Jews during the German occupation. However, this is only a small drawback. Undoubtedly, the narration created by the author deserves recognition. The narration is not straightforward, but it does not put the reader off. On the contrary, it encourages reflection. It should be added that the author creating this book used a huge amount of various sources which allow the reader to immerse in the period discussed by A. Leder.

Undoubtedly, it is a book which provokes refection. It presents events that appear to be "prehistoric" for the youngest generations because they represent the source of transformation in the society and the values that currently drive the society. Furthermore, it also justifies the absence of identity in the citizens who through the widespread ignorance cannot find their identity and, as also indicated by A. Leder, cannot trust themselves.

Prześniona Rewolucja. Ćwiczenia z logiki historycznej is a book worth recommending not only because of the fact that it presents a completely different historical and social vision. Moreover, it also presents the debate about this period and processes that took place in the 1940s and 1950s and their consequences. 